\title{
心因性要因が大きいと思われた顎関節症患者の治療経験
}

\author{
安田勝裕・中西淳仁・松本文博 - 長山勝
}

\section{TMJ arthrosis related to psychological factors: Report of a case}

\author{
Katsuhiro YasUda - Atsuhito Nakanishi - Fumihiro Matsumoto \\ Masaru NAgayama
}

\begin{abstract}
A 73-year-old female complained of pain from her right TMJ (visited our clinic) with general debility because of undernourishment. A diagnosis of TMJ arthrosis was made. Psychological factors from her past history were considered, so that occulusal and psychological therapies were given. Favorable results were obtained by the team approach of oral surgeons, prothodontists and psychiatrists.
\end{abstract}

Key words: TMJ arthrosis (靧関節症), psychological factors (心因性の要因), team approach (チームアプローチ)

緒

言

顗関節症患者には，器質的なるのよりもむしろ心因性 の要因により，その発症をみることがしばしばある。

今回，われわれは，咬合治療と共に心理面での配慮を 要し, 口腔外科, 補経科, 精神科のチームアプローチに よる治療で著効を示した顎関節症の 1 例を経験したので その概要を報告する。

\section{症}

例

\section{患 者: 73歳 女性 \\ 初 診: 昭和60年 2 月 \\ 主 訴: 右靧関節部の疼痛。}

既往歴: 腎孟炎, 不眠症, 子宮後屈, 晹癒着.

現病歴：昭和57年 8 月飞右顎関節部の雑音が生し，つ づいて著しい開口制限と開口時の疼痛が出現したため某 病院齿科を受略，咬合举上板の装着，拔歯などの治療を 受け，症状怪減した，その後近医にて義歯の製作を行 ったが，適合不良のため症状が悪化し，当院を受診し た.

\section{徳島大学㮀学部口腔外科学第 1 讙座}

\section{(主任：長山 勝教授)}

The First Department of Oral and Maxillofacial Surgery, School of Dentistry, Tokushima University (Chief: Prof. Masaru Nagayama)

受付日：平成元年 4 月 28 日
初診時現症：体格は小柄, 栄養状態はやや不良, 颜貌 は苦渋様を呈していた。頼運動時に右影関節部の疼痛, 右側頓部の王痛を認めた（写真1）.

疼涌による開口障害がみられ，開口時に下矤が左側へ 偏位し，筋突起部を触診すると压痛を認めた。口腔内は

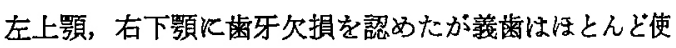
用していなかった（写真2）。

X線所見：下買頭は下罘䈑に対し両側とも後方に位置

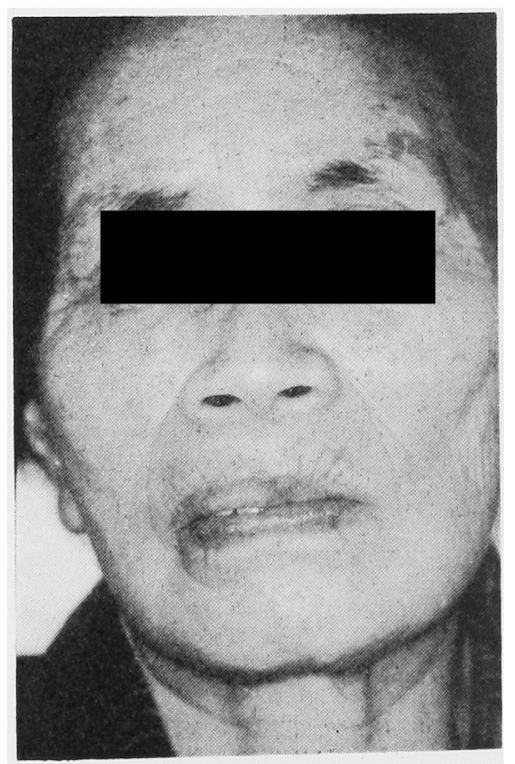

写真 1 顔貌写真 


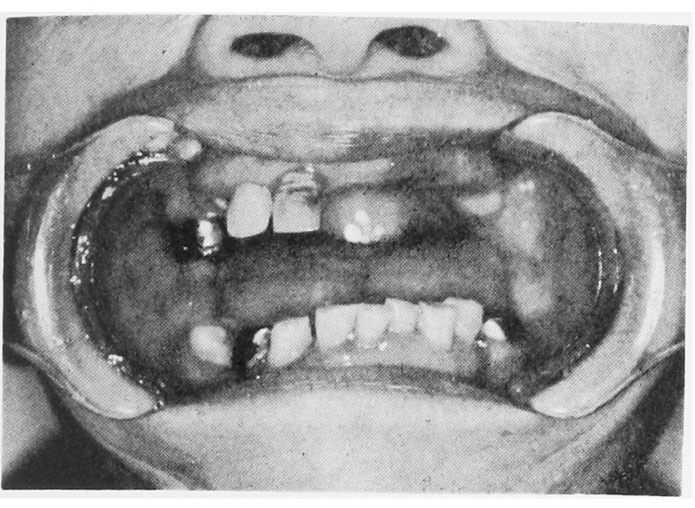

写真 2 口腔内写真

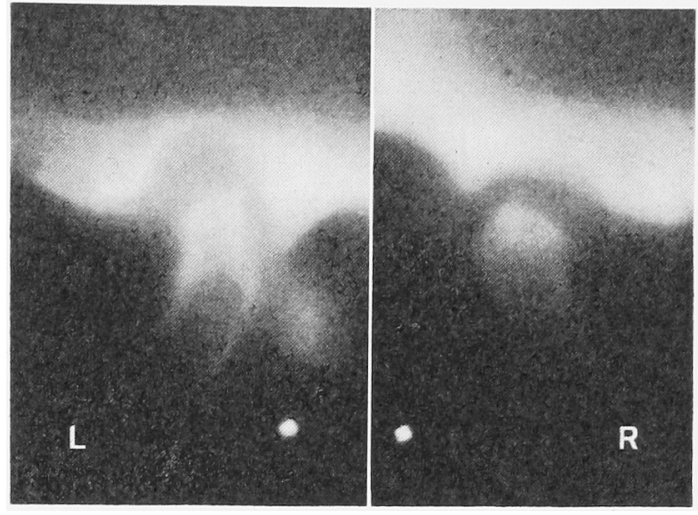

写真 3 顎関節断層 X線写真

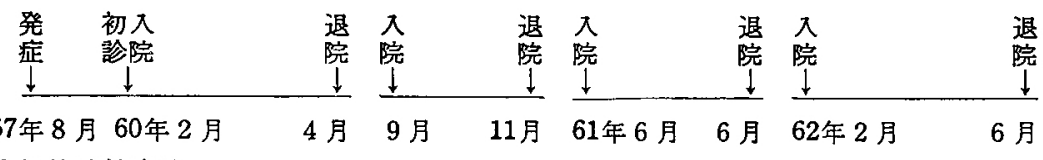

支持的精神寮法一

\section{Estazolam $2 \mathrm{mg} \quad$ Estazolam $2 \mathrm{mg}$ \\ Cloxazolam $2 \mathrm{mg}$ Triazolam $0.25 \mathrm{mg}$}

精 神 安 定 㶡

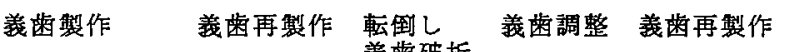

咬 合 洽 療一

口腔外科好置

\begin{tabular}{|c|c|}
\hline $\begin{array}{l}\text { |36技齿 } \\
\text { 下顎骨骨瘤除去 }\end{array}$ & 21 拔䅈 \\
\hline
\end{tabular}

图 1 洽寮経過

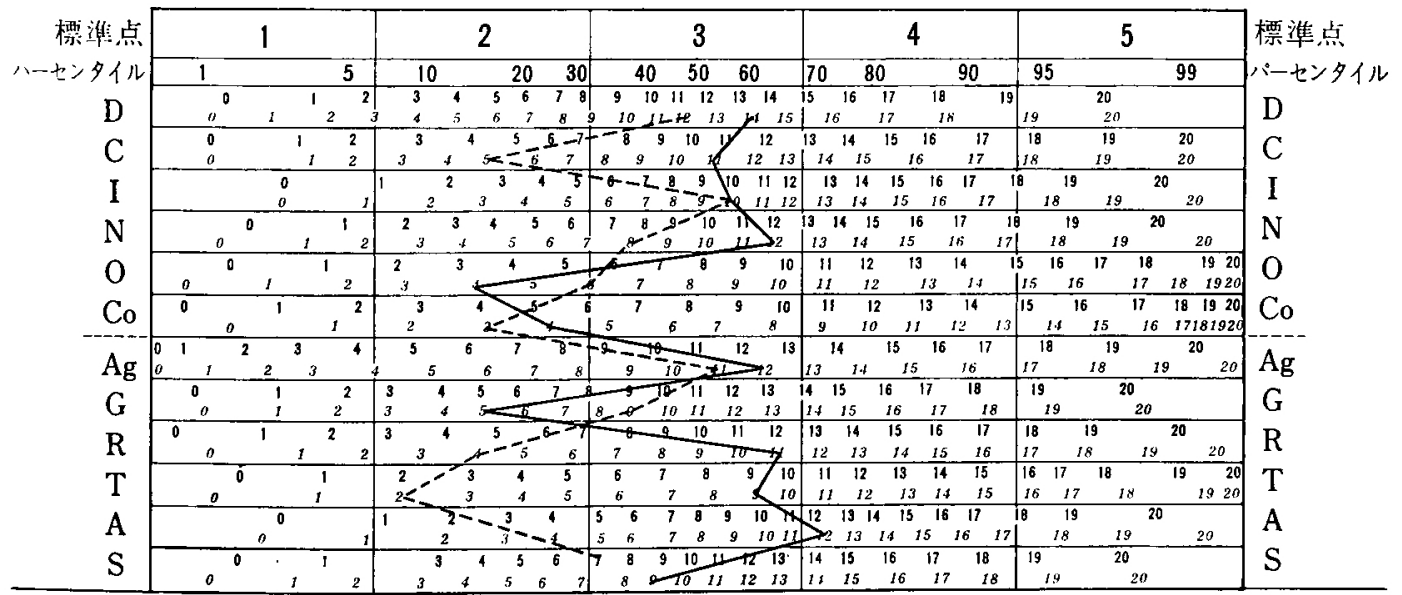

図 2 Y-G 性格検査プロフィール 
女

$(\%)$

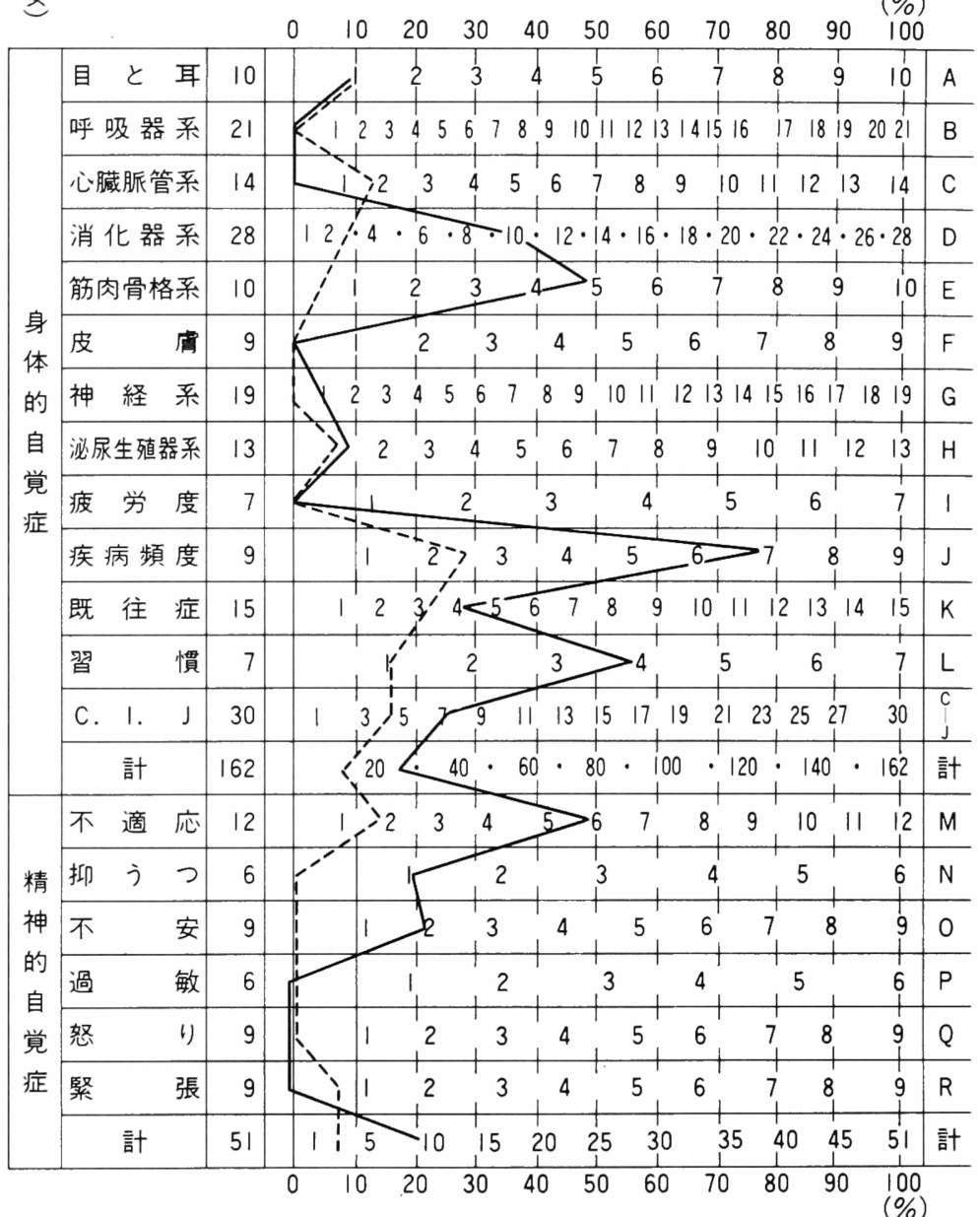

— 昭和62年2月

- - - 昭和 62 年 5 月

図 3 CMI 自覚症プロフィール

していた。また両側とも骨形態の変化がみられ非対称で あった（写真 3 ).

臨床診断 : 右側靧関節症.

経 過：全身衰弱による歩行困難と遠隔地であること を考虑して入院の上，全身状態の改善打よび咬合治療を 行うことにした。対人関係の不安と抑うつ状態，睡眠障 害, 医療不信などのため当大学精神科を受診, 神経症 (心気症), 不眠症の診断を得, 精神安定, 睡眠剤の estazolam, cloxazolam を投与された。 また，簡易精神療法 を行い，患者との信頼関係の確立に努めた。新たに製作 した義歯の装着により，咬合状態が大幅に改善され顎関 節部の疼痛, 開口障害などの症状がほば消失したため退 院した.
しかし，退院後義歯が破折，咀緭障害をきたし，極度 の栄養不良となったため再入院した。昭和 62 年 2 月入院 時, 家庭にて牛乳以外, 食事を汪とんどとって括らず, 初診時に比べ体重は $42 \mathrm{~kg}$ から $32 \mathrm{~kg}$ 一と減少し, 重 症の便秘と，それに起因すると思われる腹部違和感, さ らに oral dyskinesia を伴っていた。 また精神状態は自 己の健康状態に対し過度に不安をもって扣り, 家庭内で の欲求不満もあり抑らつ状態だった。 入院後, 流動食に よる栄養補給, 胃腸薬, 浣腸, 摘便, などによる宿便の 除去により全身状態の改善を計り, 補緅前処置として, 抜歯, 歯槽骨整形手術を行った後, 新たに義歯を装着し た。心理面に扮いては, 前回入院時と同様, 精神安定剂 や睡眠剤の投与とともに患者の悩み，訴えをよく聞き， 


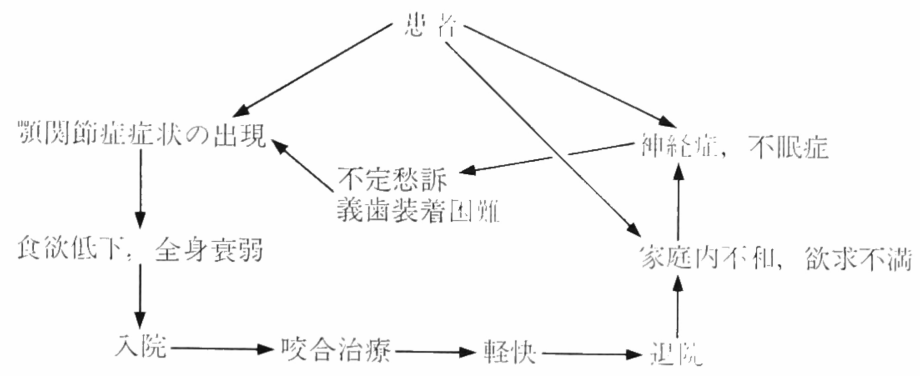

図 4 本症に拈ける顎関節症発症機序

理解に努めた（図1).

全身状態の改善, 消化器系症状の消失, 精神状態の安 定化により口腔内灼熱感の訴えもなくなり, oral dyskinesia も著明に改善した。

\section{心身医学的分析調査方法および結果}

本症例に括いて, 矢田部, ギルフォード性格検査（以 下 Y-G) ${ }^{1}$, CMI 健康調查表 (Cornell Medical Index, 以下 $\mathrm{CMI})^{2)}$ を行い図 $2 ， 3$ のよな結果を得た。実線 は昭和 62 年 2 月再入院時の最も心理的に不安定な時期の 結果で, 破線は，5 月義歯装着時の心理的に安定した時 期の結果を示している. Y-G においては非活動的な他, 特徵はみられなかったが, CMI に拈いては自覚症プロ フィールにて消化器系, 筋肉骨格系, 疾病頻度, 習慣, に高值を認めた。また精神的自覚症では不適応を示して いたが全身状態，および咬合の改善した心理的に安定な 状態になると, 破線のよらに全ての項目で著明な改善が みられた。 また神経症判別図で吕領域から II 領域への改 善がみられた（図2，3）.

さらに, SRQ-D (Self-Rating Question for Depression) 3)を行った. 心理的に不安定な時は, 仮面うつ病の 疑い(13点)を示していたが, 安定時には正常範囲( 2 点) と改善した。

\section{考察}

近年，ストレスなどの心因的な要因による顎関節症が 注目されてきており ${ }^{4 \sim 7)}$ ，顎関節症発症に拈ける心因性 の要因に関して種々の検討が行われている。高久 ${ }^{8)}$ は嶺 関節症患者において不安, 緊張, 興奮などの症状に強弱 があり, それは筋症状と因果関係があると述べている. 中村ら ${ }^{9)}$ は顎関節症に罹患したことにより心因反応性の らつ状態をきたした 1 例について報告している。 また， ストレスが顎関節症患者に拈いて有意に多く, 適切なス トレスの治療が必要という報告 ${ }^{6,7)}$ ある.

われわれの症例の経過から発症機序として図4のよ5 な図式が考えられた。すなわち, 最初は咬合異常によっ
て生じた顎関節症が家庭内不和やいろいろな欲求不満に より神経症, 不眠症を合併し, それらの要因が不定愁訴 や clenching を若起し, 咀嚼障害を生じ, 症状が悪化す ると食欲低下，全身衰弱をきたすものである，この図式 では, 咬合異常のみならず，その他の心理的な要因によ り, 容易に顎関節症症状の発症が促されることが示され ている. 同様に, Revington $5^{10)}$ も幼児期の家庭内不和 が原因と思われる開口障害を伴った22歳男性の治療経験 について報告している.

一方, 精神的要因の高い患者に特いての心理テストは その診断基準および治療効果の評価にとって重要な意義 がある。筧 ${ }^{11,12)}$ は口腔内不定疼痛症患者について CMI, Y-G，SRQ-D を行い治療効果との関連を調べており 20 〜30\%の患者に神経症的傾向の改善がみられたと述べて 牤り, 三原ら ${ }^{13)}$ は口腔心身症患者20例に CMI, Y-G を 行い症状の軽減とともにテスト值の改善がみられたこと を報告している。

顎関節症に関しては Greene 5 ${ }^{6}$ は MMPI (Minesota Multiphase Parsonality Inventory) に拈いて恐怖, 心 配, のスコアが高いことを示している。豊福ら ${ }^{14)}$ は MMPI では Hs，D，Hy が高く，CMI では III，IV領域 が多いことを述べている。内田ら ${ }^{15)}$ は, diazepam 投与 と共に CMI, Y-G での検討を行い改善がみられた後, 自律訓練療法を併用することで開口度がさらに改善した 症例を報告している。竹之下 ${ }^{16)}$ は CMI による心理的特 性の検索を行い，靧関節症患者には神経症的傾向すなわ ち情緒的障害の傾向を示すものが多く, プロフィールで は身体的自覚症 I (疲労度) J (疾病頻度), 心理的自 覚症ではO (不安) $\mathrm{R}$ (緊張) などが多かったと述べて いる。西原 ${ }^{17)}$ は 100 例におよぶ買関節症患者の心身医学 的分析を行い CMI に拈いて III 領域が多く, 男性では L (習慣), 女性ではD (消化器) F (皮虞) I (疲労度) の項目に訴えが多く，そして罹病期間が長くなるほど情 緒不安定者が増加し, 不安, 引つ傾向が強くなっていた と報告している.

われわれの症例でもCMI において症状悪化時は吕領 域を示LD (消化器系) E (筋肉骨格系) J (疾病頻度) $\mathrm{L}$ (習慣) M (不適応) の項目は訴えが多く, 他の報告 
と類似していた。これらのことからCMI は, 患者の健 康状態について心身両面にわたる自覚症状を具体的に表 現することができ，䫇関節症に㧍ちいりやすい精神状態 を示すことができると考光られた。また，CMI は心理 テストと考光にくいことより患者から回答を得やすく， ルーチン検査として採用しやすいと考劣る。一方，Y-G は記載することに抵抗感を持つためか,なかなか患者の 協力が得られず苦労を要した，CMI，Y-G，SRQ-D 以 外飞も MMPI, MAS (The modified Taylor Manifest Anxiety Scale) などでの検討も有用と思われる。

また，治療については佐藤ら ${ }^{18)}$ は，歯科治療時に傾眠 状態, 拒薬を持つ症例に対し面接を中心とした非指示的 精神療法を行い効果を得ている。枵関節症に沶いては牛 山ら 5 のように行動療法により効果を得ている場合もあ るか゚，簡易精神療法 $4,9,15,19)$ や精神安定剂の投与が一般 的である10,13,15) また患者のモチベーションやプラシー ボなども有効であるという報告6,13,20)もあるが軽症の症 例汇限定されると思われる.

今後, 難治症例については自律訓練療法 ${ }^{21)}, \mathrm{EMG}$ ： イオフィードバック法22)なども考虑する必要があろう。

このような心因性の要因を有する患者の場合, 単なる咬 合の改善のみでは買関節症症状は消失せず，咬合治療々 平行して全身状態の改善および心理的な面での配虑が必 要であると考えられた。

\section{結語}

咬合異常を伴った罘関節症により咀獣障害をきたし， 栄盖不良による全身衰弱に陥った73歳女性症例の治療経 験について報告した。本症例の治療をと扎して顎関節症 に打ける心因性要因の重要性を再確認した。

稿を終えるに臨み，患者の補経治療ならびにご教示， こ助言をいただきょした德島大学㦀学部補緅学第 2 謴座 中野雅德助教授深く感辣致します。

本論文の要旨は, 昭和 62 年 7 月 4 日第 8 回買関節研究 会（於，新渴）で報告した。

\section{引用文 献}

1）辻岡美延：新性格㭘査法 $-Y-G$ 性格检査実施, 応用, 研究手引一。第 1 版 竹井機器工業株式 会社, 東京, 1972，1-43頁。

2）金久卓也, 溁町建：コーネル・メディカル・ インデックス, その解説と資料。三京房, 京都, 1983，2-29面.

3）阿部達夫, 筒井末春, 他 : Masked depression （仮面 5つ病）のScreening test としての質問表 (SRQ-D) について。精神医 12：243-247 1972.
4) 内田安信: 口腔外科と心身医学. 茀学 67: 1161979.

5）牛山 崇, 小関英邦, 他：心因の関与が考兄ら れた，会話障害を伴った顎関節症の 1 治験例。 日口外誌 28: 497-504 1982.

6) Greene, C.S., Olson, R.E., et al.: Psychological factors in the etiology, progression, and treatment of MPD syndrome. JADA 105: 443-448 1982.

7) Fearon, C.G. and Serwatka, W.J.: Stress: A common denominator for non-organic TMJ pain-dysfunction. J Prosth Dent 49: 805-808 1983.

8）高久暹：いわ功万顎関節症の臨床的研究。日 口外誌 32:1666-1674 1986.

9）中村広一, 橋本博, 他：5つ状態に対する配 虑が治療上必要とされた罰関節症の 1 症例につ いて。 日口外誌 32：990-995 1986.

10) Revington, P.J.D., Peacock, T.R., et al.: Temporomandibular Joint Dysfunction: a Case of Hysterical Trismus. Br Dent J 158: 55-56 1985.

11）筧 敏雄：口腔不定疼痛症の特性に関する研究 (I). 日口外誌 31: 511-529 1985.

12）筧 敏雄：口腔不定疼痛症の特性汇関寸る研究 (II). 日口外誌 31：530-544 1985.

13）三原 学, 深谷昌彦, 他 : 口腔心身症に関する 臨床的検討。 日外誌 31：96-103 1985.

14）豊福司生，松瀬洋一，他：心身医学的にみた顎 関節症患者について (抄)。顎関節研究会誌 1 : 291981.

15）内田安信, 西原茂昭: 顎関節症への心身医学的 アプローチ。苗界展望 63：89-95 1984.

16）竹之下康治 : Cornell Medical Index からみた 䫇関節症。 日外誌 24:8-20 1978.

17）西原茂昭：顎関節症の心身医学的研究 第 1 編 病態扰上び発症因子に関する心身医学的分析. 日口外誌 29:454-470 1983.

18）佐藤田鶴子, 時安喜彦, 他: 俻科治癔時飞出現 した心因反応の 2 症例。 日外誌 31：771-776 1985.

19）橋本 博, 中村広一, 他: 患者の性格・心理面 への配慮が治療上必要とされたいわゆる罰関節 症の 2 症例について (抄). 顎関節研究会誌 6 : 231986.

20) Hampf, G.: Dilemma in treatment of patients suffering from orofacial dysaesthesia. Int $\mathrm{J}$ Oral Maxilloffac Surg 16: 397-401 1987

21）石井靖彦：口腔心身症に対する自律訓練法の臨 床的研究。 日只外誌 27: 388-407 1981 .

22）西原茂昭：頷関節症の心身医学的研究 第 2 編 本症に対する $\mathrm{EMG}$ ハイオフィードッックの広 用. 日斥誌 29: 471-490 1983 . 